Gut, 1982, 23, 257-264

\title{
Glycerol clearance in alcoholic liver disease
}

\author{
D G JOHNSTON, ${ }^{*}$ K G M M ALBERTI, R WRIGHT, AND P G BLAIN
}

From the Departments of Medicine, Clinical Biochemistry and Metabolic Medicine and Clinical Pharmacology, Royal Victoria Infirmary, Newcastle upon Tyne, and the Department of Medicine, Southampton General Hospital, Southampton,

SUMMARY Glycerol clearance was studied by a primed dose-constant infusion technique in 14 patients with alcoholic liver disease and six normal control subjects. Fasting blood glycerol concentrations were raised in the alcoholic subjects $(0.09 \pm 0.01 v s 0.06 \pm 0.01 \mu \mathrm{mol} / \mathrm{l}, \mathrm{P}<0.05)$ and glycerol clearance was impaired $(24.5 \pm 1.9$ vs $37.5 \pm 3.2 \mathrm{ml} / \mathrm{kg} / \mathrm{min}, \mathrm{P}<0.005)$. Endogenous production rate of glycerol and distribution space at steady state were similar in alcoholic and control subjects. The metabolic clearance rate of glycerol correlated negatively with basal glycerol concentrations. Thus tissue uptake of glycerol is impaired in liver disease. As glycerol is metabolised primarily in the liver by conversion to glucose, these data suggest a defect of gluconeogenesis in alcoholic liver disease.

The liver is the principal organ of glucose production in the fasting state ${ }^{12}$ with small contributions from the kidney and small intestine. Hypoglycaemia may complicate acute severe liver disease or end-stage chronic liver damage,${ }^{3}$ but in most patients with chronic liver disease fasting blood glucose concentrations are either normal or mildly raised. ${ }^{4}{ }^{5}$ Nonetheless, defects in glycogen storage and glycogen degradation are apparent from catheterisation experiments ${ }^{6}$ or analysis of the glycaemic response to glucagon in some $^{7}{ }^{8}$-although not all $^{9}{ }^{10}$ - studies. Little is known about gluconeogenesis in chronic liver disease but catheterisation studies suggest a compensatory increase in cirrhotics. ${ }^{11}$ This may also be inferred from radioactive tracer experiments showing normal rates of total glucose production after an overnight fast, ${ }^{12}$ although other investigators have shown a small decrease in glucose production. ${ }^{13}$

Glycerol is highly gluconeogenic in man and animals and is preferentially metabolised to glucose in favour of other gluconeogenic precursors. ${ }^{14-16}$ In fasting, $40-100 \%$ of circulating glycerol is converted to glucose, ${ }^{15} 17$ conversion increasing as blood concentrations rise. ${ }^{18}$ The liver is responsible for 70 $90 \%$ of glycerol uptake ${ }^{19} 20$ with the remainder metabolised by the kidneys, ${ }^{21} 22$ small intestine, and other tissues. ${ }^{23}$ Renal uptake of glycerol is not increased in cirrhotic man. ${ }^{6}$

Address for correspondence: Dr D G Johnston, Department of Medicine, Royal Victoria Infirmary, Newcastle upon Tyne, NE1 4LP.

Received for publication 30 July 1981
Clearance of an intravenous glycerol load may thus provide an index of liver dysfunction and an estimate of gluconeogenic capacity in cirrhotic man. We have investigated glycerol clearance in patients with alcoholic liver disease by a primed dose-constant infusion technique to steady state, with analysis of decay of blood glycerol levels on cessation of the infusion.

\section{Methods}

\section{PATIENTS}

Fourteen patients with alcoholic liver disease (11 male, three female, age 36-70 years) were compared with six normal controls (five males, one female, age 22-64 years). Eight patients had hepatic cirrhosis and six alcoholic hepatitis or fatty liver on biopsy (Table 1). The duration of heavy intake of alcohol admitted by the patients ranged from five to 30 years. Patient number 2 had mild chronic hepatic encephalopathy but no other patient was clinically in liver failure at the time of study. Patients were on a variety of medications (Table 1) but no drugs were taken on the day of study. Four patients had spontaneous portal-systemic shunting as shown by oesophageal varices on barium swallow or endoscopy, and four patients had clinically evident ascites. No patient had evidence of renal impairment. Control subjects were normal laboratory personnel or their acquaintances and none was on any drug therapy, or suffering from any known disorder. Informed consent was obtained from all subjects for the study, which was approved by the Southampton Hospitals Ethical Committee. 
Studies were performed on recumbent subjects after an overnight (10-12 hours) fast. Subjects had abstained from alcohol for at least 48 hours and had a daily carbohydrate intake in excess of $250 \mathrm{~g}$ for this period. Teflon intravenous cannulae (Venflon, Viggio, Helsingborg) were sited in an antecubital vein on each side and patency was maintained by flushing with $0.154 \mathrm{~mol} / \mathrm{l}$ saline after every sample. Thirty and 40 minutes after cannulation basal samples were taken. After an initial loading dose $(100 \mu \mathrm{mol} / \mathrm{kg}$ body weight diluted with water to isotonicity and administered over two minutes), a continuous intravenous infusion of glycerol, $19 \mu \mathrm{mol} / \mathrm{kg} / \mathrm{min}$ (Boots, Nottingham, $1.1 \mathrm{~mol} / \mathrm{l}$ ), was begun through the contralateral cannula and continued for $40 \mathrm{~min}$ utes with a Harvard continuous infusion pump. Blood samples were taken two minutes after the loading dose and at $10,7 \cdot 5,5$, and $2 \cdot 5$ minutes before the continuous infusion ended. Additional blood samples were taken $0,2 \cdot 5,5,7 \cdot 5,10,12 \cdot 5,15,20,30$, 45 , and 60 minutes after the infusion ended. All urine produced over the experimental period was collected after the last blood sample, its volume measured and a $20 \mathrm{ml}$ aliquot taken for glycerol analysis.

Venous blood $(1.5 \mathrm{ml})$ was mixed immediately with $5 \mathrm{ml}$ of $5 \%(\mathrm{~V} / \mathrm{V})$ ice-cold perchloric acid. Blood glycerol, glucose, lactate, pyruvate, and alanine were measured by an automated fluorimetric enzymatic method (Lloyd et al., 1978.24)Urine glycerol was estimated by a spectrophotometric enzymatic method. ${ }^{25}$ Plasma aspartate aminotransferase, lactate dehydrogenase, bilirubin, and albumin were measured by standard Autoanalyser techniques (Technicon).

Results are expressed as mean \pm SEM. Statistical analysis was performed using Student's paired and unpaired $t$ tests where appropriate. Correlations were sought by Spearman's ranking method. The distribution of certain data was skewed (plasma aspartate aminotransferase and bilirubin) and statistical analysis was performed on log-transformed data.

\section{MATHEMATICAL ANALYSIS}

A steady state for blood glycerol was accepted if a change of $<5 \%$ in blood glycerol concentrations occurred over the last 10 minutes of the intravenous infusion. The metabolic clearance rate (MCR, $1 / \mathrm{kg}$ / $\mathrm{min})$ was calculated as the infusion rate $(\mathrm{mmol} / \mathrm{kg} /$ min) divided by the increase in blood glycerol at steady state above the basal glycerol concentration (Gss, $\mathrm{mmol} / \mathrm{l}$ ).

$$
\operatorname{MCR}(1 / \mathrm{kg} / \mathrm{min})=\frac{\text { Infusion rate }(\mathrm{mmol} / \mathrm{kg} / \mathrm{min})}{\text { Gss }(\mathrm{mmol} / \mathrm{l})}
$$

The decay of blood glycerol when the infusion ended was closely approximated by a double ex- ponential function of the form, $A e^{-k 1 t}+\mathrm{Be}^{-k 2 t}$ where $A, B, k_{1}, k_{2}$ are constants. Curve fitting was performed by computer to the points of the blood glycerol decay curve, after the basal glycerol concentration had been subtracted, by minimising the sum of squares of deviations. The area under the curve (area, $\mathrm{mmol} / \mathrm{l} \times \mathrm{min}$ ) was calculated using the polyexponential equation. The excess amount of glycerol $(\mathrm{Qg}, \mathrm{mmol} / \mathrm{kg})$ in the body at steady state was calculated as the product of the metabolic clearance rate and the area under the decay curve.

$$
\mathrm{Qg}(\mathrm{mmol} / \mathrm{kg})=\operatorname{MCR}(1 / \mathrm{kg} / \mathrm{min}) \times
$$

area $(\mathrm{mmol} / \mathrm{l} \times \mathrm{min})$

The apparent volume of distribution of glycerol at steady state $(\mathrm{V}, 1 / \mathrm{kg})$ was calculated as the amount of glycerol present divided by the increase in blood glycerol above basal at steady state (modified from Riegelman et al. $\left.{ }^{26}\right)$.

$$
\begin{aligned}
\mathrm{V}(\mathrm{l} / \mathrm{kg})=\frac{\mathrm{Qg}(\mathrm{mmol} / \mathrm{kg})}{\mathrm{Gss}(\mathrm{mmol} / \mathrm{l})}= \\
\frac{\mathrm{MCR}(\mathrm{l} / \mathrm{kg} / \mathrm{min}) \times \operatorname{area~}(\mathrm{mmol} / \mathrm{l} \times \mathrm{min})}{\text { Gss }(\mathrm{mmol} / \mathrm{l})}
\end{aligned}
$$

The endogenous production rate of glycerol (PR, $\mu \mathrm{mol} / \mathrm{kg} / \mathrm{min}$ ) was calculated as the product of the basal glycerol concentration $(\mathrm{Gb}, \mathrm{mmol} / \mathrm{l})$ and the metabolic clearance rate.

$$
\text { PR }(\mu \mathrm{mol} / \mathrm{kg} / \mathrm{min})=\mathrm{Gb}(\mathrm{mmol} / \mathrm{l}) \times
$$

It is assumed in these calculations that the endogenous production rate of glycerol remains constant throughout the experimental period.

\section{Results}

Basal blood metabolite concentrations are shown in Table 2. Fasting blood glucose concentrations were similar in patients and controls. Blood lactate concentrations were increased by $27 \%(\mathrm{P}<0.02)$ in the patient group, but the blood lactate:pyruvate ratio was similar in patients and controls. Blood alanine levels did not differ in the two groups. Fasting blood glycerol concentration was raised in the alcoholic patients $(0.09 \pm 0.01$ vs $0.06 \pm 0.01 \mathrm{mmol} / \mathrm{l}, \mathrm{P}<0.05)$.

Data obtained during glycerol infusion are shown in Table 3. At 2.5 minutes after administration of the loading dose, blood glycerol concentrations ranged from 0.35 to $1.22 \mathrm{mmol} / \mathrm{l}$. In the patient group, glycerol infusion produced steady state glycerol concentrations of $0.91 \pm 0.05 \mathrm{mmol} / \mathrm{l}$. In the controls, steady state blood glycerol levels were $0.58 \pm 0.05$ $\mathrm{mmol} / \mathrm{l}, \mathrm{P}<0.002$ ). The metabolic clearance rate of glycerol was decreased in the alcoholics $(24.5 \pm 1.9 \mathrm{vs}$ $37.5 \pm 3.2 \mathrm{ml} / \mathrm{kg} / \mathrm{min}, \mathrm{P}<0.005)$. The apparent volume 
Table 2 Blood glucose and gluconeogenic precursor concentrations in basal state and at steady state glycerol levels in patients and controls

\begin{tabular}{|c|c|c|c|c|c|c|c|}
\hline & \multicolumn{3}{|c|}{ Basal blood metabolite concentrations ( $\mathrm{mmol} / \mathrm{l})$} & \multicolumn{4}{|c|}{$\begin{array}{l}\text { Blood metabolite concentrations ( } \mathrm{mmol} / \mathrm{l}) \text { at glycerol } \\
\text { steady state }\end{array}$} \\
\hline & Patients & Controls & $P 1$ & Patients & Controls & $P 2$ & $P 3$ \\
\hline \multirow{5}{*}{$\begin{array}{l}\text { Glucose } \\
\text { Lactate } \\
\text { Pyruvate } \\
\text { Lactate } \\
\text { Pyruvate } \\
\text { Alanine }\end{array}$} & $5 \cdot 43 \pm 0 \cdot 21$ & $5 \cdot 35 \pm 0 \cdot 31$ & NS & $5 \cdot 68 \pm 0 \cdot 23$ & $5 \cdot 65 \pm 0 \cdot 30$ & $<0.02$ & $<0.005$ \\
\hline & $0.89 \pm 0.04$ & $0.70 \pm 0.04$ & $<0.02$ & $1 \cdot 02 \pm 0.05$ & $0.85 \pm 0.06$ & $<0 \cdot 001$ & $<0 \cdot 02$ \\
\hline & $0 \cdot 09 \pm 0 \cdot 01$ & $0 \cdot 08 \pm 0 \cdot 04$ & NS & $0.09 \pm 0.01$ & $0 \cdot 08 \pm 0 \cdot 01$ & NS & NS \\
\hline & $10 \cdot 3 \pm 0 \cdot 4$ & $9 \cdot 1 \pm 0 \cdot 5$ & NS & $11 \cdot 7 \pm 0 \cdot 5$ & $10 \cdot 5 \pm 0 \cdot 3$ & $<0 \cdot 001$ & $<0 \cdot 01$ \\
\hline & $0 \cdot 27 \pm 0 \cdot 01$ & $0 \cdot 30 \pm 0 \cdot 02$ & NS & $0 \cdot 27 \pm 0 \cdot 01$ & $0 \cdot 32 \pm 0 \cdot 02$ & NS & NS \\
\hline
\end{tabular}

$\mathrm{P1}$ is the significant level for patient group different from control (unpaired test).

$\mathrm{P} 2$ is the significance level for patient group concentration at steady state different from basal concentration (paired test). $\mathrm{P} 3$ is the significance level for control group concentration at steady state different from basal concentration (paired test). NS: not significant.

For blood glucose, values $-\mathrm{mg} / 100 \mathrm{ml}$ are $18 \times \mathrm{mmol} / \mathrm{l}$.

Table 3 Glycerol infusion data in alcoholic patients and controls

\begin{tabular}{|c|c|c|c|c|}
\hline & $\begin{array}{l}\text { Steady state glycerol } \\
\text { concentration ( } \mathrm{mmol} / \mathrm{l})\end{array}$ & $\begin{array}{l}\text { Metabolic clearance } \\
\text { rate }(\mathrm{ml} / \mathrm{kg} / \mathrm{min})\end{array}$ & $\begin{array}{l}\text { Distribution space } \\
(\mathrm{l} / \mathrm{kg})\end{array}$ & $\begin{array}{l}\text { Endogenous production } \\
\text { rate }(\mu \mathrm{mol} / \mathrm{kg} / \mathrm{min})\end{array}$ \\
\hline \multicolumn{5}{|l|}{ Patient no. } \\
\hline 1 & 0.79 & $24 \cdot 5$ & $0 \cdot 564$ & $2 \cdot 08$ \\
\hline 2 & 0.96 & $20 \cdot 8$ & $0 \cdot 837$ & $2 \cdot 66$ \\
\hline 3 & $1 \cdot 07$ & $23 \cdot 0$ & $0 \cdot 866$ & $2 \cdot 25$ \\
\hline 4 & 0.69 & $29 \cdot 0$ & 0.633 & $1 \cdot 31$ \\
\hline 5 & 0.98 & $20 \cdot 1$ & $0 \cdot 845$ & 1.63 \\
\hline 6 & 0.86 & $23 \cdot 7$ & 0.379 & 1.52 \\
\hline 7 & $1 \cdot 14$ & $18 \cdot 6$ & 0.638 & $2 \cdot 38$ \\
\hline 8 & 1.09 & $18 \cdot 6$ & 0.726 & $1 \cdot 73$ \\
\hline 9 & 0.71 & $30 \cdot 4$ & 0.749 & $2 \cdot 61$ \\
\hline 10 & 0.50 & $45 \cdot 6$ & 0.821 & $2 \cdot 87$ \\
\hline 11 & $0 \cdot 79$ & $27 \cdot 4$ & 0.531 & $1 \cdot 51$ \\
\hline 12 & $1 \cdot 21$ & $16 \cdot 8$ & $0 \cdot 315$ & 1.44 \\
\hline 13 & $1 \cdot 03$ & $21 \cdot 5$ & 0.433 & $2 \cdot 06$ \\
\hline 14 & 0.86 & $22 \cdot 4$ & 0.653 & $1 \cdot 32$ \\
\hline Patient mean $\pm S E M$ & $0.91 \pm 0.05$ & $24 \cdot 5 \pm 1 \cdot 9$ & $0 \cdot 642 \pm 0 \cdot 048$ & $1 \cdot 96 \pm 0 \cdot 14$ \\
\hline \multicolumn{5}{|l|}{ Controlno. } \\
\hline 1 & $0 \cdot 70$ & $27 \cdot 5$ & 0.537 & $1 \cdot 51$ \\
\hline 2 & $0 \cdot 71$ & 32.4 & 0.746 & $2 \cdot 20$ \\
\hline 3 & 0.54 & $44 \cdot 0$ & 0.576 & 3.87 \\
\hline 4 & $0 \cdot 65$ & $33 \cdot 3$ & $0 \cdot 536$ & $1 \cdot 20$ \\
\hline 5 & $0 \cdot 50$ & $39 \cdot 5$ & $0 \cdot 886$ & 2.69 \\
\hline 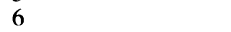 & $0 \cdot 39$ & $48 \cdot 3$ & $0 \cdot 781$ & $1 \cdot 64$ \\
\hline Control mean $\pm S E M$ & $0 \cdot 58 \pm 0 \cdot 05$ & $37 \cdot 5 \pm 3 \cdot 2$ & $0.677 \pm 0.060$ & $2 \cdot 19 \pm 0 \cdot 40$ \\
\hline Significance & $\mathrm{P}<0.002$ & $P<0.005$ & NS & NS \\
\hline
\end{tabular}

Decay of blood glycerol with time at end of the infusion was well represented by a double exponential function:

$\mathrm{y}=0 \cdot 30 \mathrm{e}^{-0 \cdot 23 \mathrm{t}}+0 \cdot 53 \mathrm{e}^{-0.03 t}$ for patients;

$y=0 \cdot 27 e^{-0 \cdot 30 t}+0 \cdot 24 e^{-0 \cdot 03 t}$ for controls.

Calculations were performed as outlined in the Methods section.

of distribution of glycerol at steady state was similar in alcoholics and controls $(0.642 \pm 0.048$ vs 0.677 $\pm 0.060 \mathrm{l} / \mathrm{kg}$ respectively).

Analysis of the decay of blood glycerol when the infusion ended showed it to be well represented by a double-exponential function (Figure). Values for the exponential constants $k_{1}$ and $k_{2}$ are shown in Table 3 with the corresponding half-life for each exponent of the decay. The half-life of the first exponent ranged from 1.4 to 9.5 minutes in the patient group and 1.8 to 3.1 minutes in the controls. The half-life for the second exponent was similar in both groups
$(27 \cdot 0 \pm 2 \cdot 4$ minutes, patients; $28 \cdot 3 \pm 3 \cdot 0$ minutes, controls).

Within the patient group, correlations were sought between the metabolic clearance rate and indices of liver function and metabolic status. Metabolic clearance rate correlated significantly and negatively with the plasma aspartate amino-transferase concentration $\left(r_{s}=-0.64, \quad P<0.02\right)$ and plasma bilirubin $\left(r_{s}=-0 \cdot 62, P<0 \cdot 05\right)$ but not with the other standard tests of liver function performed. A significant negative correlation was also obtained between the metabolic clearance rate and the basal blood glycerol 


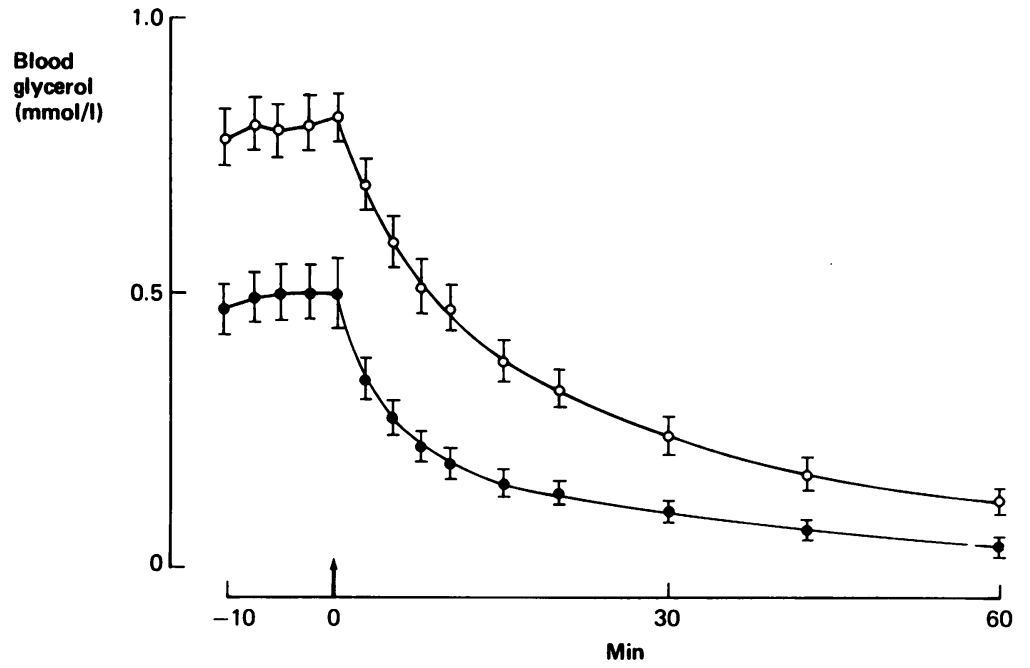

Figure Decay of blood glycerol at the end of continuous intravenous infusion. Blood glycerol expressed as change from basal values. Values shown are mean $\pm S E M$. O-O Alcoholic liver disease. $-\longrightarrow$ Control. Glycerol infusion stopped at time 0.

concentration $\left(r_{s}=-0.57, P<0.05\right)$ but no relationship was obtained with the other fasting metabolites that were estimated.

Glycerol infusion produced a rise in blood lactate concentrations ( $15 \%$ in the patients, $21 \%$ in the controls at steady state) but blood pyruvate levels were unaltered (Table 2). Blood lactate:pyruvate ratios rose in both patients and controls. Blood glucose concentrations were increased by glycerol infusion to a similar degree in patients and controls.

Urinary glycerol loss ranged from 0.1 to $1.2 \mathrm{mmol} /$ experiment and was never more than $2 \%$ of the total glycerol infused.

\section{Discussion}

Circulating concentrations of the gluconeogenic precursors, lactate, pyruvate, and glycerol, are raised in a variety of liver diseases after an overnight fast, ${ }^{34}$ and in the present study in patients with alcoholic liver disease, fasting blood lactate and glycerol concentrations were raised. These findings have usually been interpreted as secondary to diminished hepatic uptake. Impaired lactate clearance in cirrhosis has been known for many years ${ }^{27}$ and recently reaffirmed ${ }^{28}$ but information on clearance of other gluconeogenic precursors is lacking.

The metabolic clearance rate for blood glycerol $(0.038 \pm 0.003 \mathrm{l} / \mathrm{kg} / \mathrm{min})$ obtained in the present study compares with plasma clearances in the dog of 0.038 to $0.055 \mathrm{l} / \mathrm{kg} / \mathrm{min}$ over a range of circulating glycerol levels from 0.09 to $0.61 \mathrm{mmol} / \mathrm{l}$ (calculated from the tracer studies of Winkler and colleagues. ${ }^{29}$ ) Similar plasma glycerol clearances have been obtained in normal man from radioactive turnover data $(0.032$ to
$0.049 \mathrm{l} / \mathrm{kg} / \mathrm{min}$, calculated from data of Havel, ${ }^{30}$ assuming body weight of $70 \mathrm{~kg}$ ), although somewhat lower values have also been obtained $(0.024$ to 0.032 $1 / \mathrm{kg} / \mathrm{min}$, calculated from the data of Bortz et al. ${ }^{15}$ for lean subjects after a six to 14 hour fast). Estimates of clearance rates from plasma by the continuous infusion technique may be expected to produce lower values than from whole blood as the exogenous glycerol is presumably infused directly into plasma water. Equilibration of glycerol between plasma and red cells is, however, so rapid that a difference of only $10 \%$ between plasma and whole blood clearance rates may be anticipated. ${ }^{21}$ In the present study, whole blood glycerol clearance was estimated, as this may give a more accurate measure of organ uptake. ${ }^{31-33}$

The rate of glycerol uptake for metabolism in the dog is proportional to the plasma glycerol level over a plasma range of 0.06 to $1.40 \mathrm{mmol} / \mathrm{l}$, suggesting that the clearance rate is constant within this range. ${ }^{29} \mathrm{At}$ higher glycerol levels, the linear relationship is not preserved as uptake becomes saturated and significant renal glycerol excretion appears. The infusion rate of glycerol in the present study was chosen to give blood glycerol concentrations ranging from 0.5 to $1.3 \mathrm{mmol} / \mathrm{l}$. The small amounts of glycerol in the urine in the present study, which were ignored in the calculations, suggest that glycerol disposal was through metabolism rather than urinary excretion. It was also considered desirable to avoid very high circulating glycerol levels even transiently, in view of the reports of renal damage after administration of massive amounts of glycerol. ${ }^{34}{ }^{35}$ Much higher doses than those used in the present study may be administered therapeutically to man without adverse 
effects ${ }^{36}$ and no subject showed any evidence of renal impairment in this report.

The metabolic clearance rate is the best index of glycerol disappearance in this kind of experiment, as its measurement (the ratio of infusion rate to incremental glycerol concentration at steady state) is independent of any descriptive compartmental model and its estimation is valid even if glycerol elimination occurs outside the sampling compartment. ${ }^{33}$ Glycerol clearance was decreased by $35 \%$ in patients with alcoholic liver disease and clearance correlated negatively with the other indices of liver dysfunction, plasma aspartate aminotransferase, and bilirubin concentrations. Diminished clearance was found in patients with alcoholic hepatitis and fatty liver as well as in cirrhotics.

Hepatic extraction of glycerol is high. At serum levels below $1 \mathrm{mmol} / \mathrm{l}$ there is almost complete extraction in a single transhepatic passage. ${ }^{37}$ The clearance of substances with such high hepatic extraction is profoundly influenced by changes in hepatic blood flow $^{53}$ such that, if metabolism were purely hepatic and extraction $100 \%$, then the metabolic clearance rate would provide an estimate of hepatic blood flow. ${ }^{19}$ With these assumptions, the clearance rate obtained in the normal subjects $(0.031 / \mathrm{kg} / \mathrm{min})$ corresponds to a hepatic blood flow of $2 \cdot 0-2 \cdot 5 \mathrm{l} / \mathrm{min}$, as opposed to estimates by other means for normal man of $1.5-2.0 \mathrm{l} / \mathrm{min} .{ }^{38}$ Glycerol administered into a peripheral, as opposed to portal, vein, however, will also be available for metabolism by other tissues, particularly the kidneys, ${ }^{22}$ so that its clearance rate from the body will overestimate hepatic blood flow. Although no formal assessment was obtained in the alcoholic patients in this report, hepatic blood flow will undoubtedly have been diminished in some patients. ${ }^{39}$ The decrease in metabolic clearance of glycerol in alcoholic liver disease may therefore result from direct hepatocellular damage, diminished hepatic blood flow, or both. It is possible that a decrease in peripheral glycerol uptake may contribute, although this must be quantitatively small and there is no evidence to support this hypothesis.

It is assumed in our calculations that endogenous production rate of glycerol was unaltered during bulk glycerol infusion. This assumption may not be entirely valid as insulin secretion may have been stimulated by glycerol itself or the consequent rise in blood glucose. ${ }^{40}$ The resultant error in calculation of clearance rates for glycerol during bulk infusion would, however, be small. Assuming that endogenous production rate for glycerol declined to zero, an error of less than $5 \%$ in clearance estimation would be anticipated at circulating glycerol levels of $0.5 \mathrm{mmol} / \mathrm{l} .{ }^{29}$ Possible variations in endogenous glycerol production were therefore ignored in clearance estimations.
The calculated endogenous production rate of glycerol in normal subjects $(2 \cdot 19 \pm 0.40 \mu \mathrm{mol} / \mathrm{kg} / \mathrm{min})$ was similar to values from plasma data obtained in man using radioactively labelled glycerol $(1 \cdot 50 \pm 0 \cdot 23$ $\mu \mathrm{mol} / \mathrm{kg} / \mathrm{min}$ for lean subjects; $1.63 \pm 0 \cdot 22 \mu \mathrm{mol} / \mathrm{kg} /$ min for obese subjects; calculated from the data of Bortz et al. ${ }^{15}$ ) Production rates of glycerol were similar in patients with alcoholic liver disease and controls, contrasting with the increase in lipolysis inferred from studies showing increased plasma non-esterified fatty acid (NEFA) concentrations in alcoholic liver disease. ${ }^{41}$ Plasma NEFA turnover studies after adequate dietary preparation are necessary to resolve this problem. In the present report, the significant negative correlation between glycerol clearance and fasting glycerol concentrations further suggests that the raised basal glycerol levels are related to diminished uptake.

The decay of blood glycerol concentration when the infusion ended was closely approximated by a double exponential function and this was used to calculate the area under the curve. The calculated apparent volumes of distribution for glycerol by the area method ${ }^{42}(0.642 \pm 0.048 \mathrm{l} / \mathrm{kg}$ in alcoholics; $0.677 \pm 0.060 \mathrm{l} / \mathrm{kg}$ in controls) agree well with estimates in other reports suggesting distribution of glycerol within the total body water. ${ }^{30}$ If the first phase of decay of glycerol is ignored, much higher apparent volumes of distribution would be obtained in the present study, similar to values obtained for apparent glycerol space (up to $2 \cdot 1 \mathrm{l} / \mathrm{kg}$ ) by this method in the rat. ${ }^{43}$ Such calculations of distribution volume are, however, inherently subject to error. ${ }^{44}$ The volumes of distribution of glycerol in the present report were similar in alcoholics and controls, suggesting that the differences in glycerol elimination were not secondary to an altered distribution space for glycerol in alcoholic subjects.

Despite a similar rise in blood glucose in patients and controls, diminished glycerol uptake for gluconeogenesis by the diseased liver is the likely cause for the decrease in glycerol clearance in the alcoholics. Although glycerol is quantitatively a minor gluconeogenic substrate in fasting, ${ }^{45}$ conversion to glucose is the major metabolic fate. ${ }^{15} 17 \mathrm{~A}$ decreased gluconeogenic capacity in liver disease is not apparent under normal conditions, where blood glucose is either normal or mildly raised. ${ }^{4} 5$ Catheterisation studies suggest that, although splanchnic glucose production is decreased in liver disease, this decline results primarily from a decrease in glycogenolysis. ${ }^{11} 16$ Diminished splanchnic lactate uptake and glücose output in response to pharmacological doses of glucagon have, however, been reported in cirrhosis, ${ }^{46}$ although there was considerable individual variation. Gluconeogenesis is also impaired in animal models of 
liver disease such as diet-induced cirrhosis, ${ }^{47}$ galactosamine hepatitis, ${ }^{48}$ and bile duct ligation. ${ }^{49}$

Glycerol infusion caused a minor rise in blood lactate concentrations and the ratio of lactate to pyruvate in peripheral blood in both alcoholics and controls. Metabolism of glycerol increases the lactate to pyruvate ratio in the liver ${ }^{50}$ reflecting a more reduced hepatic cystolic redox state, as dihydroxyacetone phosphate is formed from glycerol-3-phosphate and enters the glycolytic-gluconeogenic pathway. ${ }^{23}$ The change in lactate:pyruvate ratio in peripheral blood may reflect these changes in the liver.

This work was founded in part by the British Diabetic Association. Dr D G Johnston is a Wellcome Senior Clinical Research Fellow.

\section{References}

1 Bernard C. Critique experimentale sur la glycemie. Des conditions physiologiques à rémplir pour constater la présence du sucre dans le sang. CR Acad Sci [D] Paris 1876; 82:1405-10.

2 Owen OE, Felig P, Morgan AP, Wahren J, Cahill GF. Liver and kidney metabolism during prolonged fasting. $J$ Clin Invest 1969; 48:574-83.

3 Alberti KGMM, Johnston DG. Carbohydrate metabolism in liver disease. In: Wright R, Alberti KGMM, Karran S, Millward-Sadler GH, eds. Liver and biliary disease. London: Saunders, 1979:44-62.

4 Johnston DG, Alberti KGMM. Carbohydrate metabolism in liver disease. Clin Endocrinol Metab 1976; 5:675-702.

5 Creutzfeldt W, Grerichs H, Sickinger K. Liver diseases and diabetes mellitus. In: Popper H, Schaffner F, eds. Progress in liver disease. London: Heinemann, 1970:371-407.

6 Owen OE, Patel MS, Block BSB, Kreulen TH, Reichle FA, Mozzoli MA. Gluconeogenesis in normal, cirrhotic and diabetic humans. In: Hanson RW, Mehlman MA, eds. Gluconeogenesis. Its regulation in mammalian species. New York, London: Heinemann, 1976:533-58.

7 Yeung RTT, Wang CCL. A study of carbohydrate metabolism in postnecrotic cirrhosis of liver. Gut 1974; 15: $907-12$

8 de Moura MC, Cruz AG. Carbohydrate metabolism studies in cirrhosis of the liver. Am J Dig Dis 1968; 13:891-906.

9 Strange RC, Mjøs OD, Hendon T, Jynge P. The effect of glucagon on plasma cyclic AMP and glucose concentrations in patients with alcoholic cirrhosis. Acta Med Scand 1977; 202:87-8.

10 Van Itallie TB, Bentley WBA. Glucagon-induced hyperglycaemia as an index of liver function. $J$ Clin Invest $1955 ; 34: 1730-7$.

11 Reichle FA, Owen OE, Golsorkhi M, Kreulen T. Hepatic metabolism in patients with alcoholic cirrhosis. Surgery $1978 ; 84: 33-6$.

12 Perez G, Trimarco B, Ungaro B, Rengo F, Sacca L. Glucoregulatory response to insulin-induced hypogly- caemia in Laennec's cirrhosis. J Clin Endocrinol Metab 1978; 46:778-83.

13 Proietto J, Alford FP, Dudley FJ. The mechanism of the carbohydrate intolerance of cirrhosis. J Clin Endocrinol Metab 1980; 51:1030-6.

14 Nikkila EA, Ojala K. Gluconeogenesis from glycerol in fasting rats. Life Sci 1964; 3:243-9.

15 Bortz WM, Paul P, Haff AC, Holmes WL. Glycerol turnover and oxidation in man. J Clin Invest 1972; 51:1537-46.

16 Steele R, Winkler B, Altszuler N. Inhibition by infused glycerol of gluconeogenesis from other precursors. $\mathrm{Am} \mathrm{J}$ Physiol 1971; 221:883-8.

17 Shaw WAS, Issekutz TB, Issekutz B Jnr. Gluconeogenesis from glycerol at rest and during exercise in normal, diabetic and methylprednisolone-treated dogs. Metabolism 1976; 25:329-39.

18 Winkler B, Rathgeb I, Steele R, Altszuler N. Conversion of glycerol to glucose in the normal dog. Am J Physiol 1970; 219:497-502.

19 Larsen JA. Elimination of glycerol as a measure of the hepatic blood flow in the cat. Acta Physiol Scand 1963; 57:224-34.

20 Gidez LI, Karnovsky ML. The metabolism of $\mathrm{C} 14$ glycerol in the intact rat. $J$ Biol Chem $1954 ; 206: 229-42$.

21 Borchgrevink CF, Havel RJ. Transport of glycerol in human blood. Proc Soc Exp Biol Med 1963; 113:946-9.

22 Swanson RE, Thompson RB. Renal tubular handling of glycerol and ethylene glycol in the dog. Am J Physiol 1969; 217:553-62.

23 Lin ECC. Glycerol utilisation and its regulation in mammals. Ann Rev Biochem 1977; 46:765-95.

24 Lloyd B, Burrin J, Smythe P, Alberti KGMM. Simple automated enzymatic fluorimetric assays for blood glucose, lactate, pyruvate, alanine, glycerol and 3hydroxybutyrate. Clin Chem 1978; 24:1724-9.

25 Eggstein M, Kreutz FH. Eine neue Bestimmung der Neutralfette im Blutserum und Gewebe. 1, Prinzip, Durchfuhrung und Besprechung der Methode. Klin Wochenschr 1966; 44:262-7.

26 Riegelman S, Loo J, Rowland M. Shortcomings in pharmacokinetic analysis by conceiving the body to exhibit properties of a single compartment. J Pharm Sci 1968; 5:117-23.

27 Soffer LJ, Dantes DA, Newburger R, Sobotka J. Metabolism of sodium D-lactate by patients with acute diffuse parenchymal injury of liver. Arch Intern Med 1937; 60:822-86.

28 Connor H, Woods HF, Murray JD, Ledingham JGG. The kinetics of elimination of a sodium L-lactate load in man: the effect of liver disease. Clin Sci Mol Med 1978; 54:33-4.

29 Winkler B, Steele R, Altszuler N. Relationship of glycerol uptake to plasma glycerol concentration in the normal dog. Am J Physiol 1969; 216:191-6.

30 Havel RJ. Some influences of the sympathetic nervous system and insulin on mobilisation of fat from adipose tissue: studies of the turnover rates of free fatty acids and glycerol. Ann NY Acad Sci 1965; 131:91-101.

31 Rowland $M$. Influence of route of administration on drug availability. J Pharm Sci 1972; 61:70-4.

32 Rowland $M$. Drug administration and regimens. In: 
Melmon KL, Morreli HF, eds. Clinical pharmacology. New York: Macmillan, 1978:25-70.

33 Wilkinson GR, Shand DG. A physiological approach to hepatic drug clearance. Clin Pharmacol Ther Invest 1971; 50:2715-25.

34 Hagnevik K, Gordon E, Lins LE, Wilhelmsson S, Forster D. Glycerol-induced haemolysis with haemoglobinuria and acute renal failure. Lancet 1974; 1:75-7.

35 Anderson RC, Harris PN, Chen KK. Toxicological studies on synthetic glycerin. J Am Pharm Ass 1950; 39:583-5.

36 Larsson O, Marinovich N, Barber K. Double blind trial of glycerol therapy in early stroke. Lancet 1976; 1: 832-4.

37 Sestoft L, Fleron P. Kinetics of glycerol uptake by the perfused rat liver. Membrane transport, phosphorylation and effect on NAD redox level. Biochim Biophy Acta 1975; 375:462-71.

38 Winkler B, Larsen JA, Munkner T, Tygstrup N. Determination of the hepatic blood flow in man by simultaneous use of five test substances measured in two parts of the liver. Scand J Clin Lab Invest 1965; 17:423-32.

39 Redeker AG, Geller HM, Reynolds TB. Hepatic wedge pressure, blood flow, vascular resistance and oxygen consumption in cirrhosis before and after end-to-side portacaval shunt. J Clin Invest 1958; 37:606-18.

40 Zanoboni A, Schwartz D, Zonoboni-Muciaccia W. Stimulation of insulin secretion in man by oral gly. cerol administration. Metabolism 1976; 25:41-5.

41 Mortiaux A, Dawson AM. Plasma free fatty acid in liver disease. Gut 1961; 2:204-9.

42 Riegelman S, Loo J, Rowland M. Concept of a volume of distribution and possible errors in evaluation of this parameter. J Pharm Sci 1968; 57:128-33.

43 Ackermann RH, Bassler KH, Wagner K. Glycerin: Ausnutzung, Umsatzkapazitat und Bickinetische daten unter intravenoser zufuhr bei der ratte. Infusion Therapie 1975; 2:9-15.

44 Riggs DS. Mathematical approach to physiological problems. Baltimore: Williams and Wilkins, 1963:209-17.

45 Wahren J, Felig P, Ahlborg G, Jorfeldt L. Glucose metabolism during leg exercise in man. $J$ Clin Invest 1971; 50:2715-25.

46 Fergulio FS, Greco F, Cesano L, Colongo PG, Sardi G, Chiandussi $\mathrm{L}$. The effects of glucagon on systemic and hepatosplanchnic haemodynamics and on net peripheral and hepatosplanchnic balance of glucose, lactic and pyruvic acids in normal subjects and cirrhotics. Clin Sci 1966; 30:43-50.

47 Henley KS, Laughrey EG, Clancy PE. Gluconeogenesis in the fatty and cirrhotic liver of the rat. The effect of oleate and ethanol. In: Lindquist $\mathrm{F}$, Tygstrup $\mathrm{N}$, eds. Regulation of hepatic metabolism. Copenhagen: Munksgaard, 1974:401-3.

48 Record CO, Alberti KGMM. Glucose tolerance and blood metabolic changes in galactosamine hepatitis and obstructive jaundice in the rat. Eur J Clin Invest 1973; 3:130-5.

49 Lee E, Ross BD, Haines JR. The effect of experimental bile duct obstruction on critical biosynthetic functions of the liver. Br J Surg 1972; 59:564-8.

50 Woods HF, Krebs HA. The effect of glycerol and dihydroxyacetone on hepatic adenine nucleotides. Biochem $J$ $1973 ; 132: 55-60$. 